\title{
Genetic Variability, Heritability in Wheat (Triticum aestivum L.) Genotypes
}

\author{
Vivek Singh $^{1 *}$, Gaurav Sharma ${ }^{1}$, Jai Prakash Verma ${ }^{2}$, Riju$^{1}$, \\ Alok Kumar Maurya ${ }^{3}$, Rajesh Kumar Singh ${ }^{1}$ and Vinod Singh ${ }^{1}$
}

${ }^{1}$ Department of genetics and plant breeding, A.N.D. University of Agriculture and technology, Kumarganj, Ayodhya, India

${ }^{2}$ Department of genetics and plant breeding Institute of Agricultural Science, BHU, Varanasi, India

${ }^{3}$ Department of genetics and plant breeding, Indian Institute of Pulse Research, Kanpur, India

*Corresponding author

\section{A B S T R A C T}

\section{Keywords}

Wheat, Genetic advance,

Coefficient of variation,

Heritability

\section{Article Info}

Accepted:

12 August 2020

Available Online:

10 September 2020

\begin{abstract}
Information on the extent of genetic variability and heritability as well as correlation among agronomical important traits is a requirement to design a suitable plant breeding method. The present research was conducted at ANDUAT, Ayodhya, India during the 2018-19 main crop growing season. The experimental material consisted of 80 wheat genotypes tested in augmented block design with three checks. Eleven agronomic traits were included in the investigation. Highly significant differences were revealed among wheat genotypes for all traits studied, suggesting the possibility of improving wheat for these traits. Peduncle length and Biological yield per plant showed the highest phenotypic and genotypic coefficients of variations and genetic advance, whereas, Spike length, days to maturity and tiller per plant had the lowest values. Peduncle length exhibited highest heritability value of $97.12 \%$ while tiller per plant showed minimum value of $17.04 \%$. Hence, these traits could be considered as suitable selection criteria for the development of high yielding wheat varieties.
\end{abstract}

\section{Introduction}

Bread wheat (Triticum aestivum) is an important food crop for more than one third of the population. The demand of wheat is increasing day by day due to increasing the population. India is second largest wheat producing nation in the world after China and account for more than 13.06 percent of the world's wheat grain production. The Directorate of Economics and Statistics estimates that the India's wheat production
2017-2018 will be 99.87 million metric tons. Wheat Production last year was 102.19 million tons which share $15 \%$ of total food grain production in 2018-19. This year's 106.21 estimated million tons could represent an increase of 7.7 million tons or a $1.06 \%$ in wheat production around the globe. Ways to sustain increasing productivity should be explored, it is now realized that sustaining as well as increasing productivity may be essential. The knowledge of factors responsible for high yield has been rendered 
difficult as yield is complex character (Singh et al., 2010). Grain yield is a complex trait and highly influenced by many genetic factors and environmental fluctuations. In plant breeding programme successful selection depends on the information on the genetic variability in base population. The estimates of genotypic coefficient of variation (GCV) reflect the total amount of genotypic variability present in material. However, the proportion of this genotypic variability which is transmitted from parents to progeny is reflected by heritability. Lush (1949) gave the concept of broad sense heritability. It determines the efficiency with which we can utilize the genotypic variability in a breeding programme.

The genotypic variance and its components are influenced by the gene frequencies. Because the frequencies of genes differ from one population to another, estimates of heritability also vary from one population to another for a given character. Burton (1952) suggested the genetic variation along with heritability estimates would give a better idea about the expected efficiency of selection thus a character possessing high GCV along the high heritability will be valuable in selection programme.

Heritability alone does not provide any indication of how much genetic change will come from choosing individual genotypes. Hence it is most important to learn about genetic development coupled with heritability. Genetic progress is an improvement over the base population in the mean of selected families (Lush 1949 and Johnson et al., 1955). It is also expressed as the change in gene frequency on the exercise of selection pressure towards the superior side. The present study is therefore, aimed at assessing genetic variation, broad sense heritability and expected genetic advance as well as relationship among agronomic traits in durum wheat.

\section{Materials and Methods}

The experimental material for the present investigation comprised 80 accessions of the drawn from wheat gene pool maintained at University mentioned in Table 1. The accessions were raised and followed recommended packages and practices during Rabi season, 2018-19. The experiment was laid out in a Augmented Block Design with three checks. Each experimental plot was 2.5 $\mathrm{m}$ long and $2.4 \mathrm{~m}$ wide, with twelve rows 20 $\mathrm{cm}$ apart, giving a gross plot area of $6 \mathrm{~m}^{2}$ and net plot area of $5 \mathrm{~m}^{2}$. Adjacent blocks were 1 $\mathrm{m}$ apart. Sowing was done by hand drilling and covered lightly with soil. The seed rate was $150 \mathrm{kgha}^{-1}$. All other agronomic practices are done as recommended for wheat production in the area.

The characters studied and techniques adopted to record the observations are given below:

1. Days to $50 \%$ flowering:

2. Days to maturity:

3. Plant height $(\mathrm{cm})$ :

4. Spike length $(\mathrm{cm})$

5. Number of productive tillers per plant:

6. Number of grains per spike:

7. Grain weight per spike:

8. Thousand-grain weight $(\mathrm{g})$ :

9. Grain yield/plant (g):

10. Biological yield per plant (g)

11. Harvest index (\%)

Variability for different characters was estimated as suggested by Burton and de Vane (1953). Heritability in broad sense was calculated as the ratio of genotypic variance to the phenotypic variance and expressed as percentage (Falconer, 1981). Genetic advance as per cent of mean for each character was worked out as suggested by Johnson et al., 
(1955).

$G C V \%=\frac{\sqrt{\text { genotypic variance }}}{\text { mean of trait }} \times 100$

$P C V \%=\frac{\sqrt{\text { phenotypic variance }}}{\text { mean of trait }} \times 100$

$\mathrm{h}_{\mathrm{B}}^{2}=\frac{\text { genotypic variance }}{\text { phenotypic variance }} \times 100$

$\mathrm{GAM}=\mathrm{k} \times \mathrm{h} 2 \frac{\sqrt{\text { phenotypic variance }}}{\text { mean of trait }} \times 100$

Where,

$\mathrm{K}=$ selection intensity $(5 \%=2.06)$,

$\mathrm{h}_{\mathrm{B}}^{2}=$ broad- sense heritability

\section{Results and Discussion}

Analysis of variance revealed highly significant differences for all characters under study among the 80 genotypes at $5 \%$ level of significance, indicating the presence of sufficient variability among genotypes.

\section{Genetic Variability}

Genotypic coefficient of variation (GCV) ranged from 2.599 to 24.41. Higher magnitude of GCV was recorded for harvest index (24.41), followed by biological yield per plant (20.426), peduncle length (18.07), days to maturity (13.46), plant height (10.4), days to $50 \%$ flowering (9.97), thousand grain weight (8.55), grain yield per plant (8.37), number of tillers per pant (6.90), flag leaf area (6.17), spike length (2.59) showed lowest GCV values.

A wide range of phenotypic coefficient of variation (PCV) was observed and ranged from 25.43 to 2.79. High magnitude of phenotypic coefficient of variation (PCV) was recorded for harvest index (25.43) followed biological yield per plant (20.97), peduncle length (18.33), number of tillers per pant (16.71), days to maturity (16.49), plant height (11.2), days to $50 \%$ flowering (10.47), thousand grain weight (10.12), grain yield per plant (9.77), flag leaf area (6.40), and spike length (2.79) showed lowest PCV values. Estimates of genotypic variance, phenotypic variance, genotypic coefficient of variation $(\mathrm{GCV})$, phenotypic of variation (PCV), heritability in broad sense $\left(\mathrm{h}^{2} \mathrm{bs}\right)$, genetic advance (GA) and genetic advance as percent of mean (GAM) are summarized in Table 1. These were also reported by Yousaf Ali et al., (2008), Zecevic et al., (2010) and Kalimullah et al., (2012).

\section{Heritability}

The estimates of genotypic coefficient of variation $(\mathrm{GCV})$ reflect the total amount of genotypic variability present in material. However, the proportion of this genotypic variability which is transmitted from parents to progeny is reflected by heritability. Lush (1949) gave the concept of broad sense heritability. It determines the efficiency with which we can utilize the genotypic variability in a breeding programme. The genotypic variance and its components are influenced by the gene frequencies. Because the frequencies of genes differ from one population to another, estimates of heritability also vary from one population to another for a given character. Burton (1952) suggested the genetic variation along with heritability estimates would give a better idea about the expected efficiency of selection thus a character possessing high GCV along the high heritability will be valuable in selection programme.

The heritability (\%) in broad sense for eleven characters studied, which range from (97.12\%) to (17.04\%).peduncle length (97.12), biological yield per plant (94.83), 
flag leaf area (92.87), harvest index (92.11), days to $50 \%$ flowering (90.56), and spike length (86.79), showed high heritability. Moderate heritability was recorded for plant height (86.35) grain yield per plant (73.51), and thousand grain weight (71.30), whereas days to maturity (66.63), and tillers per pant (17.04), showed lowest heritability. Result are in conformity with the findings of Satyavart
(2002) for spike length, Nawracaa et al., (2004) for plant height, number of grains per spike and number of spikelets per spike, Wahid Abdul and Karim Shahla (2014) also reported high heritability plant height and Kumar Naveen et al., (2013) revealed that characters exhibited high heritability for test weight

Table.1 Description of genotypes used in experiment

\begin{tabular}{|c|c|}
\hline S.No. & Genotypes \\
\hline 1 & DDK-1051 \\
\hline 2 & HW-3631 \\
\hline 3 & HD-3043 \\
\hline 4 & HTW-6 \\
\hline 5 & BRW-3723 \\
\hline 6 & HUW-699 \\
\hline 7 & HI- 8765 \\
\hline 8 & HI-8708 (d) \\
\hline 9 & HS-626 \\
\hline 10 & MACS-3949 (d) \\
\hline 11 & WH-1127 \\
\hline 12 & DBW-110 \\
\hline 13 & TL-3007 \\
\hline 14 & HI-8737 (d) \\
\hline 15 & PBW-756 \\
\hline 16 & NIAW-1994 \\
\hline 17 & HI-8751 \\
\hline 18 & PDW-344 \\
\hline 19 & DBW-105 \\
\hline 20 & HI-8777 (d) \\
\hline 21 & HS-627 \\
\hline 22 & DBW-129 \\
\hline 23 & WH-1216 \\
\hline 24 & K-1006 \\
\hline 25 & GJW-463 \\
\hline 26 & HI-8759 \\
\hline 27 & AKAW-3717 \\
\hline 28 & K-1317 \\
\hline 29 & DBW-39 \\
\hline 30 & HI-1612 \\
\hline 31 & DWAP-1530 \\
\hline 32 & HIKK-09 \\
\hline 33 & KBRL-82-2 \\
\hline 34 & PBW-725 \\
\hline 35 & HD-3171 \\
\hline 36 & TL-3006 \\
\hline 37 & COH-1105 \\
\hline
\end{tabular}




\begin{tabular}{|l|l|}
\hline 38 & DHTW-60 \\
\hline 39 & HTW-11 \\
\hline 40 & HW-5207 \\
\hline 41 & KBRL-79-2 \\
\hline 42 & UASD-DT-6 \\
\hline 43 & AKAW-4901 \\
\hline 44 & CG-1013 \\
\hline 45 & DBW-187 \\
\hline 46 & DBW-88 \\
\hline 47 & HI-1620 \\
\hline 48 & MACS-5044 \\
\hline 49 & DBW-246 \\
\hline 50 & KRL-283 \\
\hline 51 & MP-3382 \\
\hline 52 & PWD-752 \\
\hline 53 & UAS-334 \\
\hline 54 & UAS-357 \\
\hline 55 & WH-1080 \\
\hline 56 & AKAW-4927 \\
\hline 57 & DBW-173 \\
\hline 58 & DBW-93 \\
\hline 59 & DBW-179 \\
\hline 60 & FLW-10 \\
\hline 61 & FLW-22 \\
\hline 62 & HIKK-05 \\
\hline 63 & HTW-9 \\
\hline 64 & PBW-703 \\
\hline 65 & PWD-757 \\
\hline 66 & DBW-71 \\
\hline 67 & HD-1609 \\
\hline 68 & HD-3086 \\
\hline 69 & FLW-16 \\
\hline 70 & HIKK-06 \\
\hline 71 & WH-1310 \\
\hline 72 & GRU-2010-18/7 \\
\hline 73 & HD-3237 \\
\hline 74 & DBW-220 \\
\hline 75 & PBW-760 \\
\hline 76 & UAS-459 \\
\hline 77 & WH-730 \\
\hline 78 & DBW-107 \\
\hline 79 & DWAP-1531 \\
\hline 80 & HD-2967 (CH.) \\
\hline 81 & SO-8713 $(C H)$. \\
\hline
\end{tabular}


Table.2 Estimates of genetic parameters for eleven agro-morphological traits in wheat

\begin{tabular}{|c|c|c|c|c|c|c|}
\hline \multirow[t]{2}{*}{ Traits } & \multirow{2}{*}{$\begin{array}{l}\text { Heritability } \\
\quad(\%)\end{array}$} & \multicolumn{2}{|c|}{ Coefficient of Variations } & \multirow{2}{*}{$\begin{array}{l}\text { Genetic } \\
\text { Advance }\end{array}$} & \multirow{2}{*}{$\begin{array}{c}\text { Genetic Advance } \\
\text { as \% means }\end{array}$} & \multirow{2}{*}{$\begin{array}{l}\text { Block (adj) } \\
\quad \text { (MSS) }\end{array}$} \\
\hline & & Genotypic & Phenotypic & & & \\
\hline DFF & 90.563 & 9.971 & 10.478 & 11.161 & 19.548 & 6.3 \\
\hline FLA & 92.874 & 6.17 & 6.402 & 8.904 & 12.249 & $32.58^{*}$ \\
\hline PH & 86.352 & 10.408 & 11.2 & 4.231 & 19.924 & $117.9^{*}$ \\
\hline DM & 66.636 & 13.461 & 16.49 & 2.354 & 22.636 & 0.75 \\
\hline TP & 17.041 & 6.901 & 16.718 & 0.074 & 5.869 & 0.52 \\
\hline SL & 86.799 & 2.599 & 2.79 & 5.944 & 4.988 & 5.20 \\
\hline PL & 97.121 & 18.071 & 18.337 & 20.097 & 36.687 & $7.24 ?^{*}$ \\
\hline BYP & 94.813 & 20.426 & 20.978 & 12.943 & 40.972 & $98.07 *$ \\
\hline GYP & 73.51 & 8.379 & 9.773 & 6.539 & 14.799 & 21.62 \\
\hline TW & 71.301 & 8.55 & 10.126 & 3.213 & 14.872 & 6.87 \\
\hline HI & 92.11 & 24.41 & 25.434 & 6.768 & 48.26 & 42.33 \\
\hline
\end{tabular}

\section{Genetic advance as percent of mean}

Heritability alone does not provide any indication of how much genetic change will come from choosing individual genotypes. Hence it is most important to learn about genetic development coupled with heritability. Genetic progress is an improvement over the base population in the mean of selected families (Lush 1949 and Johnson et al., 1955). It is also expressed as the change in gene frequency on the exercise of selection pressure towards the superior side.

A character with high heritability cannot automatically offer substantial genetic advancement. Johnson et al., (1955) suggested that heritability and genetic advancement would prove more useful when computed together, predicting the resulting effect of selection on phenotypic expression. Maximum genetic improvement was reported for peduncle length (20.09), biological yield per plant (40.97) and flowering days to 50 percent (11.16). However, for harvest index (48.26), biological yield per plant (40.97) and peduncle length (36.68) a high estimate of genetic progress as a percent of the mean was reported similar observation were reported by Kalimullah et al., (2012) and Vamshikrishna Nukasani et al., (2013) reported high heritability coupled with high genetic advance for traits grain weight per spike and grains per spike.

According to Paul K et al., (2006) high heritability along with high genetic advance was observed for grains weight per spike, grain per spike length, plant height and productive tillers.

In conclusion the studies on variability, heritability and genetic advance showed that biological yield per plant, peduncle length, days to $50 \%$ flowering, flag leaf area, days to maturity, followed by grain yield per plant, are having considerable importance to breeder for selection. Because of this additive variability, selection for these characters would be highly sensitive, and a superior genotype could be produced as the environment had the least impact on the speech of these characters. 


\section{References}

Abdul Wahid Baloch, Shahla Karim Baloch, Siraj Ahmed Channa, Abdul Majeed Baloch, M.Ali, Masood Ahmed Junejo and Gul Muhammad Baloch (2014). Character association and heritability analysis in elite bread wheat cultivars International Journal of Applied Biology and Pharmaceutical Technology vol.5 issue-4

Muhammad, A. (2013). Morphological and genetic diversity of Pakistani wheat germplasm under drought stress. International Journal of Advancements in Research \& Technology. 2. 186-193.

Ahmad, M. Q., Hassan, M., Qayyum, A., Saleem, M. A., Malik, W., Noor, E., \&Ul-Allah, S. (2019). Characterization of Synthetic Wheat Germplasm using Morphological and Molecular Markers. International Journal of Agriculture and Biology, 22(1), 131138.

Breiman A, Graur B (1995). Wheat Evolution. Israel J. Plant Sci. 43: 85-98.

Briggle, L.W., (1980). Origin and botany of wheat. In E. Hafliger, ed. Wheat documenta.

Burton, G.W. (1952).Quantitative inheritance in grasses. Proc. 6th Int. Grasslands Cong. J., 1:227-283

Burton, G.W. and Devane(1953)Estimating heritability in tall Fesscue from replicated clonal marterial. Agron. J., (45): 474-481.

Chaitali, S. and Bini, T., (2007) Variability, character association and component analysis in wheat (T. aestivum L.) Crop Research, (Hisar). 34 (1-3): 166-170.

Dergicho Dutamo, Sentayehu Alamerew Dr. Firdisa Eticha and Gezahegn Fikre (2015). Genetic Variability in Bread Wheat (Triticum aestivum L.) germplasm for yield and yield component traits. Journal of Biology,
Agriculture and Healthcare Vol.5, No.13

Donald, C.M. (1968). The breeding of crop ideotypes. Euphytica, 17: 385-403.

Dutamo, D., Alamerew, S., Eticha, F. and Assefa, E. (2015). Genetic variability in bread wheat (Triticum aestivum L.) germplasm for yield and yield component traits. Journal of Biology, Agriculture and Health care, 5(17): 140-147.

Gowda, D., Singh, G. and Singh, Anju.(2011). Relationship between canopy temperature depression, membrane stability, relative water content and grain yield in bread wheat (Triticum aestivum) under heat-stress environments. Indian Journal of Agricultural Sciences. 81. 197-202.

Falconer, D. S. (1960).Introduction to Quantitative Genetics. Oliver and Boyd, London.

Falconer, D. S. (1981).Introduction to Quantitative Genetics, Second edition. Longman, New York.

Johnson, H.W., Robinson, H.F. and Comstock, R.E. (1955).Genotypic and phenotypic correlations in soybean and their implication in selection. Agron. J., 47: 47- 483.

Kallim Ullah Khan, SJ Muhammad Irfaq, Tila Muhammad, Saeed Muhammad, (2012). Genotypic and Phenotypic Variability, Heritability and genetic diversity for yield components in bread wheat (Triticum aestivum L.) germplasm. African Journal of Agricultural research, vol.6 no.23 pp 5204-5207.

Kumar, D. and S.A. Kerkhi. (2015). Genetic variability, heritability and genetic advance for yield component and quality traits in spring wheat (Triticum aestivum L.). Bioscan. 10(4): 21252129

Lush, J.L. (1949). Heritability of quantitative characters in farm animals. 
Proceedings of the 8th International Congress on Genetics. Genetics Supliment. Heredits, 356395.

Nukasani, V., Potdukhe, N.R., Bharad, S., Deshmukh, S. and Shinde, S.M. (2013). Genetic variability, correlation and path analysis in wheat. J. Wheat Res, 5(2): 48-51.

Paul, A. K., Islam, M. A., Hasan, M. J., Choudhary, M. M. H. and Choudhary, A.Z.M.K.A (2006).Genetic variation of some morpho-physiological characters in triticum durum wheat.International $J$. of Sustainable Agricultural Technology. 2 (8): 11-14

Ranjana, Suresh Kumar, (2013). Study of genetic variability and heritability over extended dates of sowing in bread wheat (Triticum aestivum L.). Research in Plant Biology vol. 3 no 1 pp 33-36.

Salem, Khaled; El-Zanaty, A. and Esmail, Ramadan. (2008). Assessing Wheat (Triticum aestivum L.) Genetic
Diversity Using Morphological Characters and Microsatallite Markers. World Journal of Agriculture Science. 4. 538-544.

Taneva, K., Bozhanova, V., and Petrova, I., (2019). Variability, heritability and genetic advance of some grain quality traits and grain yield in durum wheat genotypes. Bulg. Jour. of Agri Sci. Vol. 25. 288-295.

Yousaf A.A., Javed Akhter Monneveux B.M., Zahid Lateef, P., (2008). Genetic variability, association and diversity studies in wheat (Triticum aestivum $\mathrm{L}$. em Thell.) germplasm. Pakistan Journal of Botany. 40 (5): 2087-2097.

Zecevic, V., Boskovic, J., Dimitrijevic, M., and Petrovic, S., (2010). Genetic and phenotypic variability of yield components in wheat (Triticum aestivum L.em.Thell.). Bulgarian Journal of Agricultural Science. 16 (4): $422-428$

\section{How to cite this article:}

Vivek Singh, Gaurav Sharma, Jai Prakash Verma, Riju, Alok Kumar Maurya, Rajesh Kumar Singh and Vinod Singh. 2020. Genetic Variability, Heritability in Wheat (Triticum aestivum L.) Genotypes Int.J.Curr.Microbiol.App.Sci. 9(09): 1600-1607. doi: https://doi.org/10.20546/ijcmas.2020.909.199 